\title{
Vietnam's Fisheries and Aquaculture Development's Policy: Are Exports Performance Targets Sustainable?
}

\author{
Hong Thi Khanh Nguyen ${ }^{1}$, Phan Thi Thu Hien ${ }^{2}$, Tran Thi Nang Thu ${ }^{3}$ and Philippe Lebailly ${ }^{1 *}$ \\ ${ }^{1}$ University of Liège, Belgium \\ ${ }^{2}$ Foreign Trade University, Vietnam \\ ${ }^{3}$ Vietnam National University of Agriculture, Vietnam
}

Submission: October 17, 2017; Published: December 22, 2017

*Corresponding author: Philippe Lebailly, Gembloux Agro BioTech, University of Liège, Belgium, Email: philippe.lebailly@ulg.ac.be

\begin{abstract}
The Master Plan through 2020 and vision to 2030 (here called the Master Plan) on Vietnam's fisheries and aquaculture development aims to ensure this sector will be leading commodity producer by focusing on high value-added growth and sustainable development. Although, in the past Vietnam has achieved high growth rates in seafood exports, problems with the policy making process and implementing the Master Plan's road map are major obstacles to achieving the sustainability targets. By pointing out the main impacts of seafood exports on Vietnam's environment, economics and society and comparing the current situation with the fundamentals of sustainable development, the authors assess the efficiency and effectiveness of the Vietnam Master Plan, as well as its sustainability. Furthermore, the paper urges Vietnamese seafood exporters to acknowledge the importance of sustainable development when adapting to the international sea legislation and developing technical standards. This is intended to answer a big question of Vietnam's fisheries and aquaculture sectors: How to ensure an adequate focus on sustainable development while promoting increased exports and international competitiveness in the context of globalization and FTAs?
\end{abstract}

Some key findings of the research include:

1. A big gap exists between the sustainability goal of Vietnam's Master Plan and the current situation regarding the environment, economics and society as it relates to Vietnam's fishery exports.

2. Sustainable development requires Vietnam's policy makers to adopt detailed roadmaps for implementation and

3. Lack of active participation by the industry in policy development and marine infrastructure development strategy for seafood exports and supply chains in aquaculture is impeding productivity increases and the international competitiveness of the Vietnam's fishery exports.

\section{Background}

Fish represents around $20 \%$ of the animal protein consumed worldwide and plays an important role in global food security and nutrition. Global consumption of aquaculture products is forecasted to rise over the long-term and the market prospects for fish and seafood continue to be positive. Continued population growth and rising standards of living including advance global demand for aquaculture products, and a consequent increase in pressure on natural resources and negative effects on the environment [1].

World fish production is projected to grow at $1.5 \%$ during the 2016-2025 period (a slowdown relative to the $2.5 \%$ of the previous decade). Accordingly, levels of production are expected to reach $196 \mathrm{Mt}$ in 2025. Most of the production growth for fish will take place in Asia. The majority of growth will come from aquaculture, which will surpass total capture fisheries in 2021. Despite the increasing role of aquaculture in total fish supply, the capture sector is expected to remain dominant for a number of species, and vital for domestic and international food security. Aquaculture will continue to be one of the fastest growing food sectors despite its average annual growth rate slowing from $5.4 \%$ in the previous decade to $3.0 \%$ in the period 2016-25. Much of the increase is expected in freshwater species. In 2025, fish originating from aquaculture is expected to represent $57 \%$ of fish consumed worldwide [2].

The global fisheries and aquaculture sector faces many challenges. Many fisheries are overfished, overcapitalized and suffer from low returns and limited prospects. Aquaculture has grown tremendously, but future growth is threatened by the environmental impacts of production, its dependence on wild fish as feedstock, and competition for space where it operates. To solve these problems, the sectors will have to embrace reform that will put them on the path to greener growth and long-term sustainability [3]. 
During previous years, along with the overall development of Vietnam, the fisheries sector has made great progress in terms of output and is a cornerstone of the Vietnamese economy. The average growth rate of this sector has been $7.9 \%$ per year contributing greatly to the industrialization and modernization of the agriculture and rural sectors of the country. Since 2006, Vietnam has been globally ranked among the top 10 leading exporting countries in fisheries. Significantly, fishery is Vietnam's fifth largest export item after garments, electronics, crude oil and footwear, and accounts for an estimated 4-5\% of Vietnam's GDP. In 2015 , the total value of aquaculture production contributed to approximately $65 \%$ of Vietnam's total fisheries exports, equivalent to US $\$ 4.26$ billion. It provides around 4 million jobs throughout the country. Accordingly, the sector plays an important role in the country's economy.

In addition, the integration process of Vietnam to the global economy has a great impact on the development policy of this segment. Since 1990's, Vietnam has been very active in participating to global economy by signing Bilateral Trade Agreement with the United States in 2001 and especially becoming a member of the World Trade Organization (WTO) in 2007. As a member of ASEAN countries, Vietnam involved in several ASEAN + Free Trade Agreements (FTA) with many countries including China, Japan, Korea, India, Australia, and New Zealand. The process of opening Vietnam's economy was remarkable made by the conclusion of the two mega FTAs with higher level of liberalization including Trans-Pacific Partnership (TPP) agreement and Vietnam - EU FTA (EVFTA) in 2015. And just recently, in October 2016 the FTA between Vietnam and States of Eurasian Economic Union (EAEU) also came into force. The integration process and FTAs have brought huge benefits for Vietnam Seafood products entering to the world markets with tax incentives however this also requires the Government, businesses, farmers and relevant stakeholders to build a comprehensive approach to overcome strict non-tariff barriers which may be applicable differently among countries.

Nonetheless, the supply chain of seafood in Vietnam has not been effectively designed and operated, and has not contributed to the sustainability of the sector. Problems include the protection of resources, limitations in traceability, food safety issues and lack of branding/eco-certification. Vietnam's seafood exporting achievements are leading to a wide range of socioeconomic negative impacts on rural and coastal areas where economic opportunities are limited as well as wild fish stocks in Vietnam.

Within this context, Vietnam Government has also taken a great consideration on regulating and promoting the sustainable development of this industry. Since 2010, many legal documents such as the Strategy, Master Plans and Decisions have been issued to guide the sector growing in a sustainable way by balancing the economic, social and environmental benefits. The Vietnamese Government aims to lead the country to become a global leading seafood exporter. According to the Master plan issued on 16 August 2013 by the Prime Minister, a number of specific targets include total fisheries production will reach 7 million tons by 2020 and 9 million tons by 2030, of which aquaculture production will account for $65 \%$ then reach 70 $\%$ later on. The value of seafood export will be around US $\$ 11$ billion by 2020 with the average growth rates are 7-8\%, then by 2030 this value will reach US $\$ 20$ billion with the slower growth rates of $6-7 \%$. Moreover, this sector is targeted to provide training for $50 \%$ of fishery laborers by 2020 and $80 \%$ by 2030 . Following the principles set out in the Strategy and Master plan, recently on 28 May 2014, the Ministry of Agriculture and Rural Development (MARD) approved an Action plan to restructure the Fishery and Aquaculture sector to ensure it will be leading commodity producer by focusing on high value-added growth and sustainable development.

The objective of this article is first to characterize the recent nature of Vietnam's seafood exports performance. Second, to analyseVietnam's fisheries and aquaculture development's policies, especially the Master Plan by 2020 and 2030 with a particular attention linking to the sustainability of exports performance in future. This is intended to answer a big question of Vietnam's fisheries and aquaculture sectors: How to ensure the Vietnam's sustainable export performance with high international competitiveness in the context of globalization and FTAs?

\section{Vietnam's Seafood Exports Performance and Related Issues on Sustainability}

\section{Growth rates of export value}

In 2015, seafood export turnover of Vietnam reached $\$ 6.5$ billion, which increased $240 \%$ since 2005 with a record of US $\$ 7$, 7 billion in 2014. Table 1 based on the statistics of General Department of Vietnam Customs (GDVC) presents the evolution of export value during the last decade. The average growth rate of $14.32 \%$ is actually double the strategic target $(7 \%$ - $8 \%$ over the period of 2011 - 2020) which leads to a question whether the projection is appropriate?

Table 1: Vietnam Seafood Export by Value: 2005-2015.

\begin{tabular}{|c|c|c|}
\hline Year & Value (Million US\$) & Growth rate (\%) \\
\hline 2005 & 2,697 & \\
\hline 2006 & 3,325 & 23.29 \\
\hline 2007 & 3,762 & 13.14 \\
\hline 2008 & 4,500 & 19.62 \\
\hline 2009 & 4,250 & -5.56 \\
\hline 2010 & 5,033 & 18.42 \\
\hline 2011 & 6,089 & 20.98 \\
\hline 2012 & 6,076 & -0.21 \\
\hline 2013 & 6,677 & 9.89 \\
\hline 2014 & 7,775 & 16.44 \\
\hline 2015 & 6,558 & -15.65 \\
\hline
\end{tabular}

Firstly, it is important to evaluate the efficiency of seafood export value by breaking down the components of the export 
value. Nguyen Tien Hung (MARD, 2008) compared the average prices and the export volumes in each market and came up with a conclusion that from 2001 to 2008, the increase of seafood export values mostly were due the export volumes (100\% in 2001-2002 and from 2005-2008). Applying the same methodology in a longer period, the study showed that during the time from 1994-2014, overall, the volume component accounted for $64.27 \%$ of the increase in total export value where as the price component only contributed to $35.73 \%$ ) [4]. This study indicated that the increase of seafood export value during the last decade due to the volume component was not efficient. If the price element went up, it could improve the economic efficiency by not expanding the cultivating, processing and store spaces, reducing pollution effects while maintaining the domestic materials supply and demand [5].

Secondly, GDVC's statistics also show that while the export value increased with some reductions in different years (in 2009,2012 , and 2015), seafood import value has been steadily up over the same time. The table below shows the rate of import value over the export value, which is continuously growing from $9 \%$ to $16 \%$ in the period of 2011-2015 (Table 2). Particularly, in 2015 while the export value dropped by $15.65 \%$, the import value conversely increased by $16 \%$. The rise in import of seafood for export first obviously made the sector became dependent to foreign suppliers, created competition with the domestic industry thus failed to develop the Vietnamese aquaculture sector and moreover maybe reduce the profit margin in the long term. Currently, Vietnam Government is providing favorable conditions to attract more foreign direct investment and create jobs for the work force by giving tax incentives to materials import for export processing. Therefore, many companies have taken this advantage to process seafood for export from import materials. In the long run, this competitive advantage is not sustainable as it doesn't bring high added value to the sector while the Government has to give up considerable tax revenue (Figure 1).

Table 2: Vietnam Seafood import over export value: 2011-2015. Table 2: Vietnam Seafood import over export value: 2011-2015.

\begin{tabular}{|c|c|c|c|c|c|}
\hline & 2011 & 2012 & 2013 & 2014 & 2015 \\
\hline & Value (\$US mil) & Value (\$US mil) & Value (\$US mil) & Value (\$US mil) & Value (\$US mil) \\
\hline Export value & 6.089 & 6.076 & 6.677 & 7.775 & 6.557 \\
\hline Import Value & 539 & 654 & 720 & 1.066 & 1.067 \\
\hline Imp/Exp & $9 \%$ & $11 \%$ & $11 \%$ & $14 \%$ & $16 \%$ \\
\hline
\end{tabular}

Source: GDVC, 2016.

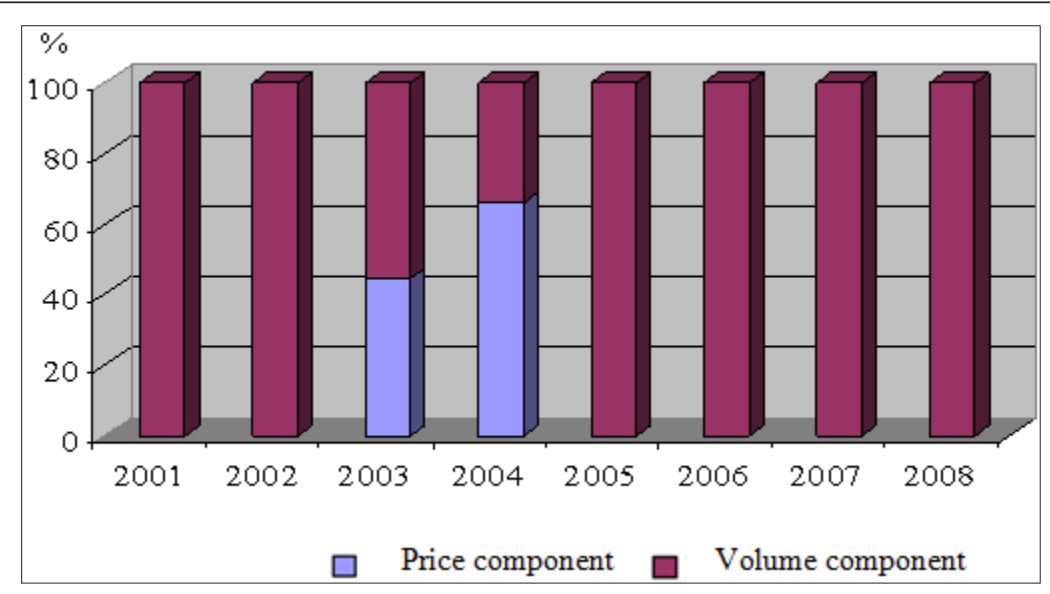

Figure 1: The Efficiency of the seafood export value: 2001-2008.

Source: MARD, 2008.

\section{Seafood export commodity}

With respect to export of key products, the goals of the 2020 Plan are increasing the percentage of pangasius export to $45.9 \%$ and the share of shrimp export remains at $32.3 \%$. Its objectives also maintain large market shares in the traditional markets such as the EU, US and Japan and expand to other markets in
Asian Pacific region. The structure of Vietnam export fishery products to the world from 2011-2015 was shown in Figure 2. In reality, shrimp has been always the biggest export product accounting for between $37 \%$ and $51 \%$ of total seafood exports, followed by pangasius (23\%-31\%), while mollucks and tuna shared the same proportion (5\%-9\%). 


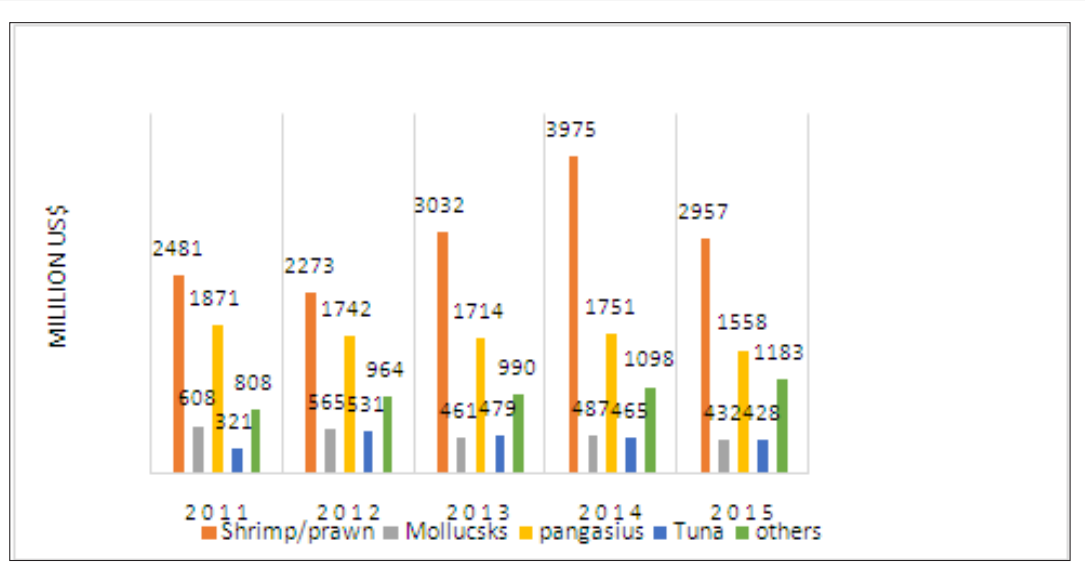

Figure 2 : Structure of Vietnam Export Seafood products to the World in 2011-2015. Source: GDVC, 2016.

Table 3: Vietnam shrimp exported to the EU: 2011-2015. Op6

\begin{tabular}{|c|c|c|c|c|c|}
\hline & $\mathbf{2 0 1 1}$ & $\mathbf{2 0 1 2}$ & $\mathbf{2 0 1 3}$ & $\mathbf{2 0 1 4}$ & $\mathbf{2 0 1 5}$ \\
\hline $\begin{array}{c}\text { Shrimp/prawn (HS } \\
\text { 03\&16) }\end{array}$ & 421 ( US\$m) & 316 ( US\$m) & 395 (US\$m) & 672 (US\$m) & 539 (US\$m) \\
\hline Growth rate & $-24.91 \%$ & $24.85 \%$ & $70.00 \%$ & $-19.70 \%$ \\
\hline $\begin{array}{c}\% \text { of VN shrimp to the } \\
\text { world }\end{array}$ & $16.99 \%$ & $13.92 \%$ & $13.03 \%$ & $16.90 \%$ & $18.24 \%$ \\
\hline $\begin{array}{c}\% \text { of total VN seafood } \\
\text { export to the EU }\end{array}$ & $30.87 \%$ & $27.84 \%$ & $34.39 \%$ & $48.10 \%$ & $46.64 \%$ \\
\hline
\end{tabular}

Source: GDVC, 2016.

Shrimp has accounted for a big part of Vietnam seafood exports to the EU and its market share has increased from $30.87 \%$ in 2011 to $46.64 \%$ in 2015 of the total seafood export to the EU and from $16.99 \%$ to $18.24 \%$ of the total Vietnamese shrimp exported to the world accordingly (Table 3). However, the growth rates evolution seems not sustainable because while it dropped by $24.91 \%$ in 2012 , it recovered in 2013 by a rise of $24.85 \%$ then surprisingly climbed up to $70 \%$ in 2014 after the again dropped in 2015 by $19.7 \%$. The fluctuation of shrimp exports to the EU also raised a concern of sustainability for this sector.

In terms of origins, shrimp of Vietnam "wholly obtained" origin enjoys the GSP preferential tariff rate which is not applicable to other countries such as India. Therefore a sharp increase of live/fresh/frozen shrimps imported from India to Vietnam $(+30 \%)$ and accordingly a surprised increase of processed shrimp exports from Vietnam to the EU (+70\%) in 2014 might cause an issue of mis-declaration of rules of origins for shrimp "wholly obtained" of Vietnam destined to the EU. This issue could be easily avoided if the regulations on health certificates and issuing certificates of origin are well implemented. On the other hand, the training and guidance for business to understand the requirements on rules of origins in preferential tax scheme is also critically important to help business avoid making non intentional frauds.

\section{Export markets}

With respect to export markets, Figure 2 shows that the US remains the largest importer for Vietnam fishery products $(20 \%$ of export value in 2015), followed by EU (18\%) and Japan (16\%). While the traditional markets still make an important role in Vietnam Seafood export, the opportunities to enter these markets are becoming increasingly difficult because of highly strict food standards, origin traceability, and anti-dumping duties. Recently, more barriers for Vietnamese catfish export to the US given by the introduction of Farm Bill and the requirement of IUU fishing in the EU took effect since 2010 give lots of obstacles for Vietnam seafood. As a result, Vietnamese seafood exporters have explored other easier markets to deal with such as China. The export volume to China increased sharply by more than 2 times within 5 years. According to VASEP, by September 2016, total value of catfish exports to China reached US\$201.9 million, more than $75.6 \%$ over the same period of 2015 making China overtake the EU to become the second largest importer for pangasius of Vietnam [6]. However, dealing with Chinese middlemen has brought the risks of unstable demand and the price dropping as many lessons learned that Vietnamese farmers have had in the past. While the interference of the Vietnamese authorities has been very limited, recently many Mekong River Delta catfish farmers have experienced big losses [7]. 
Vietnam has also imported more and more seafood materials for export with the value increased by two digits rates. India is the largest seafood supplier to Vietnam recently with the import value grew from $16 \%$ in 2011 to $33.25 \%$ in 2014 and $30.15 \%$ in 2015 (Table 4). 99\% of seafood import from India was shrimp with an estimated value of US\$318 million, occupied $74.7 \%$ of total shrimp imports by Vietnam in 2015 that makes Vietnam the second biggest shrimp importer for India. The increasing dependence of shrimp import from India in the long run will not only affect the business efficiency because of reduced profit margin but also negatively impact the sustainable development of the Vietnam shrimp aquaculture.

Table 4: Main import markets of Vietnam's fishery products from 2011-2015.

\begin{tabular}{|c|c|c|c|c|c|}
\hline & 2011 & 2012 & 2013 & 2014 & 2015 \\
\hline Countries of origin & Import value & Import value & Import value & Import value & Import value \\
\hline India & $86,181,261$ & $58,248,126$ & $168,445,291$ & $354,623,415$ & $321,978,858$ \\
\hline$\%$ & $15.98 \%$ & $8.90 \%$ & $23.39 \%$ & $33.25 \%$ & $30.15 \%$ \\
\hline Taiwan & $55,977,637$ & $63,008,403$ & $75,678,270$ & $75,758,674$ & $89,253,499$ \\
\hline$\%$ & $10.38 \%$ & $9.63 \%$ & $10.51 \%$ & $7.10 \%$ & $8.36 \%$ \\
\hline Norway & $33,498,165$ & $41,509,460$ & $46,434,462$ & $66,036,047$ & $78,984,295$ \\
\hline$\%$ & $6.21 \%$ & $6.34 \%$ & $6.45 \%$ & $6.19 \%$ & $7.40 \%$ \\
\hline Japan & $41,465,425$ & $51,818,149$ & $57,291,196$ & $61,345,485$ & $65,620,754$ \\
\hline$\%$ & $7.69 \%$ & $7.92 \%$ & $7.95 \%$ & $5.75 \%$ & $6.15 \%$ \\
\hline
\end{tabular}

Unit: USD.

Source: GDVC, 2016.

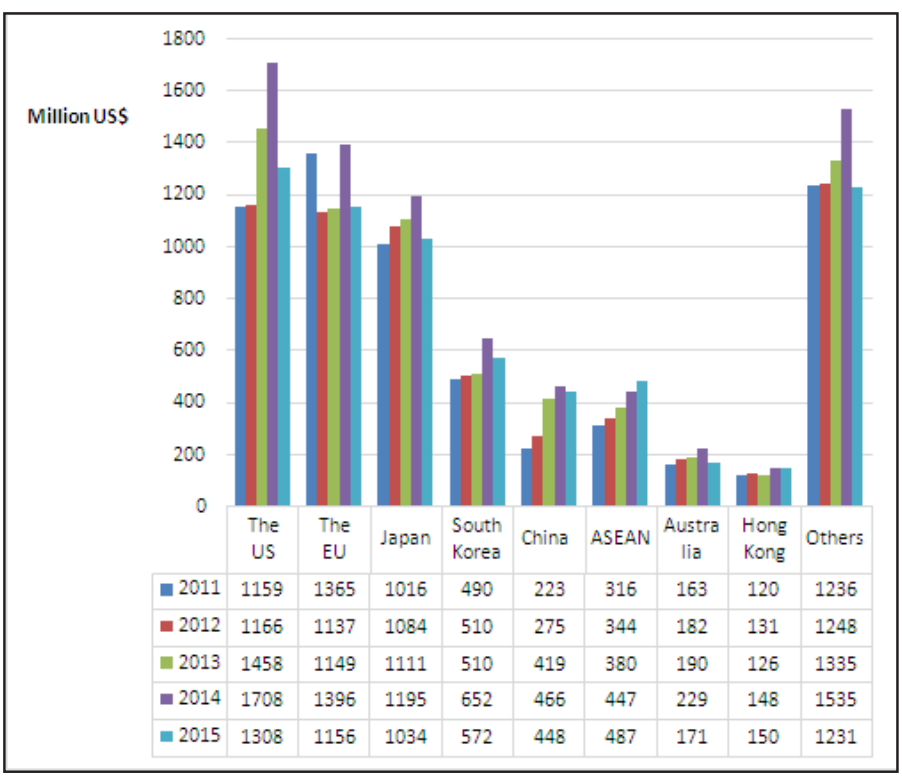

Figure 3: Main export markets of Vietnam' fishery products in 2011-2015.

Source: GDVC, 2016.

In reality, to maintain the traditionally big markets such as the US, EU and Japan as indicated in the Master Plan is not an easy job but really crucial for Vietnam Seafood sector. In recent times, due to concerns of antibiotic residues and banned chemicals, there were a high percentage of Vietnam seafood shipments being rejected by importing countries such as the EU, the US and Japan detected [8]. Vietnam government on one hand, need to consciously take a good care of this issue, provide an adequate training, maintain a transparent mechanism to warn and thus help other business to avoid the same problems. The government on the other hand, in collaboration with other stakeholders such as business association needs to create an information exchange channel to continuously update the market situation, consumption estimation to provide for business. To deal with new emerging markets, the Government should take a key role in monitor the supply and demand flows, providing adequate information to support business expanding the market shares as well as avoid risks which may arise (Figure 3). 
Major Concerns of Vietnam's Sustainable Exports Performance

\section{Feed industry}

The development of the aquaculture sector has resulted in an increased demand for aquaculture feed. According to Pham Anh Tuan, the feed stuff accounts for $75-80 \%$ of input cost of the aquaculture production. A reason for that is the feeding industry has to import $90 \%$ materials (maize, soybean, fish powder) from overseas markets. According to GDVC, maize import value increased more than 4.35 times from 2011 to 2015, especially in 2015 its import value reached US $\$ 1.65$ billion. For soybean, import volume was 1.6 times more in 2015 compared to 2011 with the value reaching US\$764 million in 2015. This fact shows a problem in the strategic direction because Vietnam is one of the world biggest rice exporter why it cannot produce maize and soybean? OECD studies on Vietnam Agricultural policies (2015) showed that rice has been given much more incentives than maize, especially on the farming land. But this priority should be reconsidered based on cost - benefit analysis (Figure 4).

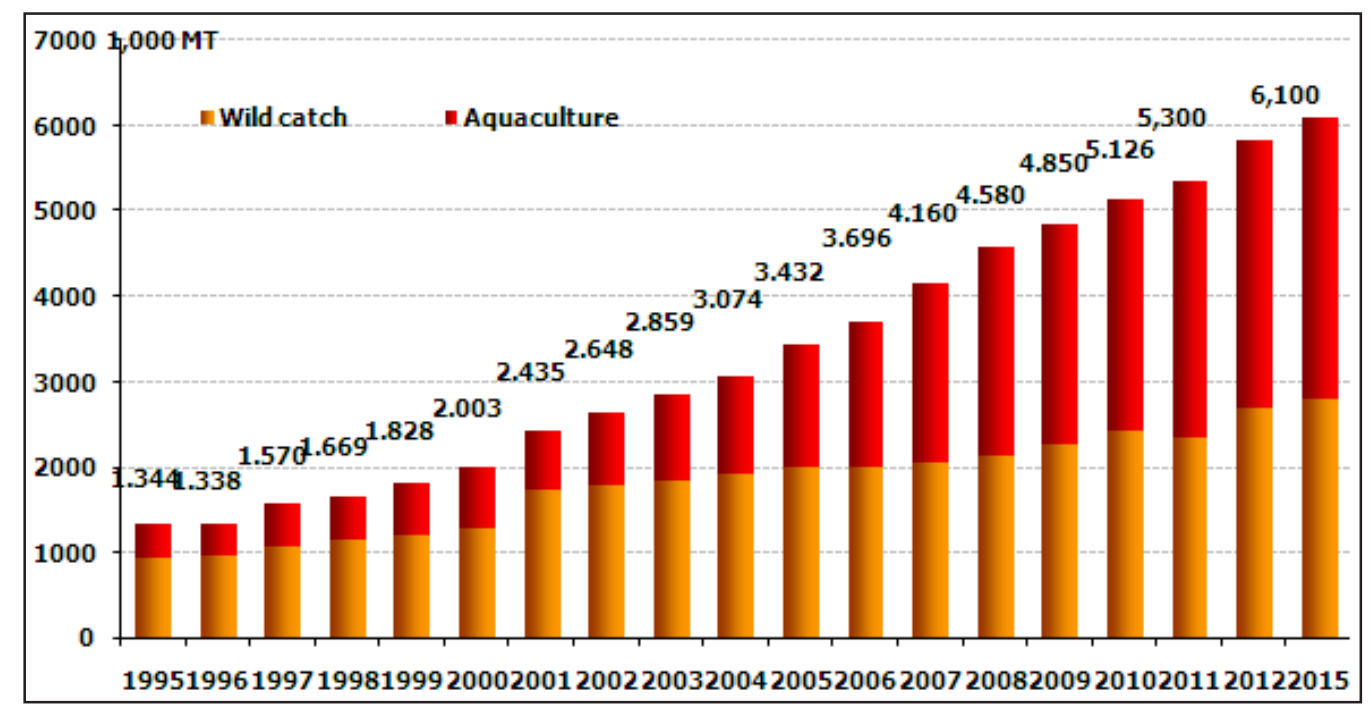

Figure 4: Volume of exporting aquaculture.

Source: Ministry of Agriculture and Rural Developmen, 2015.

On the other hand, the feed industry is highly fragmented, most businesses are small or medium sized operations and they have lost the most market share to foreign companies. There are about 15 large feed producers owned by foreign companies or joint ventures that produce about $60 \%$ of all of Vietnam's manufactured animal feed. It is observed that in Vietnam there is a hard competition between companies in the feed industry while this sector is not encouraged to cooperate and to exchange information on feed formulation. To stimulate the production and adoption of fishmeal replacers, their environmental benefit and avoidance of overfishing should be taken into account. Feeding by trash fish is particularly damaging to the environment due to a fall in substantial proportions of feed. These practices are unsustainable and should be replaced by better feeds and feeding practices.

Finally, it could be convinced that the feed sector currently is developed without a proper strategy as the Government has too much focused on rice production and exportation. While the feed sector is heavily dependent on foreign suppliers, the lack of control in input materials price is obvious for the livestock and the aquaculture sector particularly. Furthermore, the Master plan for fish and aquaculture sector by 2020 hasn't been built in conjunction with that of the feed industry which results in a big gap for a sustainable and high value added fish and aquaculture sector in the years to come.

\section{Structure of wild fishing and aquaculture}

On the aspect of sustainable development, the structure of Vietnam seafood exports has positively improving due to the percentage of aquaculture products volume in the total exports gradually increases to approximately $50 \%$. This makes export performance targets in long term unsustainable due to a wide range of factors like natural conditions, laws and regulations on marine resources and environment as well as seamen behaviors, etc.

However, the increasing volume of exporting aquaculture mainly contributes to grows of feeding industry and imports value of Vietnam' fisheries and aquaculture recently. As Table 2 shows that, the ratios imports and exports of this sector had grown up from $9 \%$ in 2009 to $16 \%$ in 2016 . This is not a good signal for a sustainable development and exports performance and becomes harder when many FTAs come into force with lower import barriers. Lacks of technical standards and qualified feeding conditions, quality of Vietnam-fed aquaculture are known to be risky and dangerous to consumers in many countries. This is also main reason of decline in exports 
performance of Vietnamese seafood in developed markets like USA, EU and Japan recently.

\section{Master Plan of Vietnam Fisheries and Aquaculture Development T 2020 and Vision to 2030}

The Master Plan of Vietnam Fisheries and Aquaculture Development through 2020 and vision to 2030 was issued on September 16, 2013 aims to develop Vietnam's fisheries and aquaculture to 2020 with major targets as follows:

I. To increase international competitiveness and high productivity in the context of globalization and regional integration.

II. To foster modernization and industrialization of Vietnam's fisheries and aquaculture while protecting environment and marine ecosystem in the coastal areas.

III. To reinforce sustainability of Vietnam's fisheries and aquaculture which successfully composes three pillars of environment, economics and society objectives.

In details, sustainable development of rural areas must include four processes industrialization and modernization; urbanization; population control; environmental protection. Focus investments on developing living infrastructure and improving the life quality of farmers in terms of economic, cultural, social, environmental and democratic aspects.

In principles, this is a comprehensive plan for long-term development of Vietnam's fisheries and aquaculture which synchronizes all aspects of innovation such as wild fish catching and fish stock conservation; aquaculture in various spaces of water; processing and commercial consumption in the domestic and international markets; mechanical ship building and fishing logistics service. The Master Plan also design strategic programs of fisheries and aquacultures development based on the real conditions, competing factors and natural characteristics in major centers of Vietnam including Red River Delta; Northern Centre and central coast areas; Eastern South, Mekong river delta and mountainous areas in the Eastern North and Tay Nguyen.

Aiming to an effective and efficient implementation, the Master Plan delivers a wide range of solutions with administering roles of the related governmental agencies. This pays most concerns on sustainability development and international competitiveness of Vietnam's fisheries and aquacultures with sustainable-oriented solutions highly focusing on reproductive seafood supply chains; intensively marketing and trade promotion; human resource enhancement, technological renovations, R\&D; fishing occupational supports and protection of marine, coastal, island environment and development of marine resources; international cooperation.

Finally, aiming to enhance effectiveness of State management towards accelerating administrative reform, coordination among relevant stakeholders in implementing the Strategy, the Master Plan had appointed different working responsibilities and scopes of ministries, governmental agencies and relevant stakeholders like business community, VASEP.

In the implementing progress of this Strategy, Vietnam Government has issued many supporting policies and action plans to successfully achieve the sustainable development objectives by 2020 and vision to 2030. However, these Master plans and Action plans were not issued in an inclusive manner which reduced the effectiveness if the implementation process.

In general, Vietnam's fisheries and aquaculture development policies have completely shed a light for sustainability as well as seafood exports enhancement stretching whole global supply chains of Vietnamese products from sourcing to end consumption. Nonetheless, to sustainable exports performance objectives and execution, the Strategy and other relevant policies reveal some limitations and weakness as presented below.

Firstly, indicating a specific figures of production yields with gradually increasing portions of aquaculture; exports turnover to 2020 that were 6.5 to 7 million MT in which aquaculture accounts for $65-70 \%$; and US\$ 8 to 10 billion in respectively. Other sustainability-related factors of this industry like catching locations, aquaculture production spaces, productivity, livelihoods of farmers and fishmen, living standards in fishing villages, etc. Specially, this also indicated the major trade partners as the current situation like EU, USA, Japan, Brazil for exports and India, Taiwan, China for imports. It seems unrealistic and scientific-analyzed objectives because this sector's performance mainly depends on the nature conditions and human being behaviors in the industrialization and urbanization.

Furthermore, Vietnam is accelerating international integrations with widely becoming signatory members of many FTAs and mega cooperation mechanisms like TPP, EVFTA, Vietnam-EUEA, etc. which has been creating many direct impacts on the national environment, labor and trade legislations and certainly the Vietnam aquaculture operation and exports performance. This should be replaced by comparative targets for seafood exports performance like international market shares, value-added growth, and total exports cost efficiency, essentially these must be designed on the ground of various scientific and computerized internal and external business environment analyses. Furthermore, it needs particular targets in short-term and adjusted periodically in alignment with the international and national socio-economic developments.

Secondly, IUU and traceability matters are raising concerns of many Vietnam' seafood importers in the world like EU, Japan, USA but Vietnam has not pay appropriate attention in policy making process as well as strategic schemes, action plans. The Strategy just mentioned relevant information and solutions like locally feeding reorganization, food security, applying international standards and technical practices. The relevant regulated document which explicitly regulate issues of preventing, deterring and eliminating Illegal Unregulated and Unreported (IUU) fishing in Vietnam was coming into force 3 years 
after the Master Plan. This results in problems of origin, safety products and documentary frauds of Vietnam seafood exports in the international markets in a very long time. In recent time, Vietnam is the second country after China having the highest numbers of seafood export shipments being rejected [9]. Lacks of official legislation frameworks and implementing capacity on IUU fishing and traceability, Vietnam are facing threatens of IUU seafood imports from other countries in the world and partly transferred into export manufacturing processing.

In addition, lacks of IT infrastructure and integrated information exchange between stakeholders in the sea food supply chains as well as with the governmental agencies makes the traceability of Vietnam's trade partners impossible and costly. So there are few Vietnamese seafood exporters who can keep exports performance sustainable and competitive like Minh Phu Cor. and Vinh Hao Co. in USA market. Certainly, this will happens in other markets when tariff barriers are replaced by non-tariff ones in many FTAs of Vietnam.

Vietnam should improve enforcement capacity in traceability and IUU, reinforce the proper awareness and general action plans on IUU issues for sustainable exports targets in future. The Vietnamese seafood exports really need technical assistance and consultation from the administrations to certify legally origin and traceability [9-15].

Thirdly, the Master Plan indicated many solutions and initiatives to support Vietnam's fisheries and aquacultures in general and seafood exports in particularly but all of them are in written forms and slightly in connection with international commitments of Vietnam about trade facilitation, subsidies or Aid for Trade and tariff and non-tariff measures. As a member of WTO and many FTAs, Vietnam is actively conducting legislation renovation and transparent and competitive business environment but there are big gaps between documentary regulations and implementation as well as different level of governance and supervisions. This should be eliminated by an information exchanging mechanism between the policy makers and relevant stakeholders like farmers, trader, foreign investors, local authorities, etc.

Consequently, the Master Plan just showed willingness of Vietnam Government to enhance ocean natural resources, to promote exports, productivity as well as social welfares in relation to the Vietnam's fisheries and aquaculture development without sufficient, coherent strategic schemes, action plans and performance report which ensure the success of the Government policies [16-22].

Finally, the Master Plan clearly appointed numerous Ministries and Administrations in implementing for sustainability and global competitiveness but there is no coordination and/or a central supervising mechanism to govern the implementing process and periodic assessments and adjustment. People have discussed about the 4 parties alliance of policy makers; farmers; traders and academia which provide an effective and efficient implementation for sustainability of Vietnam's seafood exports to 2020 and vision to 2030. Although, several fishing centers in different coast regions in Vietnam and professional associations like VASEP are appointed as the connecting hubs in this process but there has not been any regulation regulating rights and obligations, working mechanism for their connecting roles between the enterprises and the Government. How to determine their legal functions and professional careers as is also unanswered now [22-29].

\section{Conclusion and Recommendations}

The Master Plan on Vietnam's fisheries and aquaculture development through 2020 and vision 2030 aims to develop this sector as the Vietnam's leading commodity producer by focusing on high value-added growth and sustainable development. Although, in the past Vietnam has achieved high growth rates in seafood exports, problems with the policy making process, as well as implementing the Master Plan's road map are major obstacles to achieving the sustainability targets. Lack of a comprehensive attention to the need for sustainability and comprehensive action plans to increase Vietnam's seafood exports can have many negative impacts on the environment, the economy and society. Many of these negative impacts are already affecting Vietnam's export performance, such as low value-added, weak reaction in the international market fluctuations, limitations in traceability, food safety issues and a lack of branding/eco-certification. After five years of steady increases, in 2015 the value of Vietnam's seafood exports decreased by around 16\% from the 2014 level General Department of Vietnam Customs, 2016.

To affirm sustainability of Vietnam's seafood export performance by 2002 and vision to 2030, the authors suggest some recommendations for the Vietnam's fisheries and aquaculture development policies of Vietnam as follows.

Firstly, building a comprehensive conceptual framework of sustainability development and seafood export performance with an indicators system for measuring and evaluating the sustainability of the Vietnam's fisheries and aquaculture industry is essential. This includes not only the Vietnam national standards, but also a wide range of technical criteria, international norms and practices. By reviewing international trade regulations stipulated in WTO, TPP and other FTAs, Vietnam should develop reliable data on fisheries subsidies and adopt fisheries subsidies disciplines among a core group of partner countries.

Regarding to IUU fishing and traceability, Vietnam should strongly declare market access conditions and remedies to prevent, deter and eliminate these products outbound and inbound of the country. On the regional and international negotiation and governmental submit meetings, Vietnam actively engage in creating a network of regional measures to address IUU fishing. Vietnam should issue legal framework for operation of independent testing and inspection services suppliers for Vietnam's seafood exports shipment in order to 
comply requirements of origin, IUU and traceability in different importing markets.

Vietnam should reinforce awareness and educations about this global issue for all stakeholders in the industry. Mass media, VASEP' information channel are major contributing factors for an effective fight against IUU fishing in Vietnam and this should be put in the implementation.

Secondly, harmonizing and standardizing tariff and nontariff measures for sustainable and high value-added exports performance. It relates to many unprohibited measures of Aid for Trade in framework of multinational agreements like WTO, TPP and EVFTA. Vietnam should take advantages from these negotiations to implement a wide range of supporting and subsidies measures relatively. In addition, Vietnam should flexibly integrates tariff and non-tariff measures under regional and multinational integrations like: differentiating between capture and aquaculture fish in HS codes; making coherence between private standards and the TBT codes on standards, assisting exporting SMEs to establish and reach professional standards; building a link mutual recognition systems for standards applicable to fish products. All the measures and practices must be legally regulated and transparently publication with a variety of technical assistance information and practices as well as efficient consultations through the country.

Thirdly, as many fishery developing models in the world like England, India, Thailand Vietnam should establish a centrally competent authority like a committee or board who is in charge of implementing the Master Plan. It is high power and wide working scope in legal issues and disputes arising from the exports of Vietnam in the international markets. Member should come from different stakeholders and sectors in the economy like MARD, VASEP, and academia. This will be a primary bridge connecting the Government agencies and the seafood exporters and producers to make policy and implement the Vietnam's Master Plan.

\section{Acknowledgement}

This study is a collaborative research between the University of Liège - Gembloux Agro BioTech (Belgium), Foreign Trade University and the University of Agriculture (Vietnam).

\section{References}

1. FAO (2014) The State of World Fisheries and Aquaculture. p. 243.

2. OECD/FAO (2016) Fish, in OECD-FAO Agricultural Outlook 2016. OECD Publishing, Paris, Italy.

3. OECD (2015) Vietnam Agricultural Policies.

4. VASEP (2015) Annual Report 2015, Vietnam Association of Seafood Exporters and Producers

5. VASEP (2015) Shrimp imports into Vietnam in 2015.

6. VASEP (2016) China became the second biggest importer of Vietnam pangasius.
7. Thuy san Vietnam (2016) Future of sustainable feed.

8. Tuoitrenews (2016) Vietnam catfish farmers indebted as demand from Chinese market drops.

9. Tuoitrenews (2016) EU issues alert on unsafe Vietnamese seafood exports.

10. Chalmin PH (2016) Rapport Cyclope 2016 A la recherché des sommets perdus. ECONOMICA.

11. Cremer M, Chappel J, Jian Z, Enhua Z (2014) New Intensive Pond Aquaculture Technology Demonstrated in China. Global Aquaculture Advocate, p. 62.

12. David Hayes (2016) Vietnam targets US\$7 billion fisheries export. World Fishing and Aquaculture.

13. Ho TK Phuong, Le MH Giao, Vu LA, Le KT (2014) OMIS Report VNM 0496. UK Trade and Investment, England, p. 46.

14. Ho Thi Minh Hop, Burny PH (2015) Impact of value chain governance on the development of small scale shrimp farmers in Vietnam. In: Petropoulos D, Kyriazopoulos G (Eds.), $1^{\text {st }}$ International Conference of Development and Economy (ICODECON): The advantages and disadvantages of Economic Crises: Book of abstracts.

15. HLPE (2014) Sustainable fisheries and aquaculture for food security and nutrition. The High Level Panel of Experts on Food Security and Nutrition.

16. GDVC (2016) Vietnam Seafood import and export data, 2011-2015.

17. IFFO (2012) Aquaculture and Green Growth workshop, Presentation given at the Green Growth and Aquaculture Workshop, Yeosu, Korea.

18. Nguyen Minh Duc (2011) Value chain analysis, Vietnam. Nong Lam University, Vietnam.

19. Nguyen HN (2013) Vietnam seafood export: opportunities \& challenges. Vietnam Association of Seafood Exporters \& Producers (VASEP), p. 37.

20. Nguyet A Vu (2013) Fishery Industry in Vietnam. Vietin bank Sc Industry, Report, 16.

21. Nguyen Tien Hung (2008) MARD.

22. Nguyen Tien Hung (2015) MARD.

23. OECD (2015) Green Growth in Fisheries and Aquaculture, OECD Green Growth Studies, OECD Publishing, Paris, Italy, p. 116.

24. Pham Anh Tuan, IPSARD (2016) Thủy sản Việt Nam phát triển bền vững.

25. Tacon AGJ, Metian TM (2009) Fishing for feed or fishing for food: increasing global competition for small pelagic forage fish. Ambio 38(6): 294-302.

26. Tuoitrenews (2016) Fish quality in central Vietnam remains unclear following mass deaths.

27. UNEP (2009) Fisheries subsidies, supply chain and certification in Vietnam. Summary report (Ministry of Fisheries and the World Bank, 2005). Vietnam Fisheries and Aquaculture Sector.

28. Van Duijn AP, Beukers R, van der Pijl W (2012) The Vietnamese seafood sector. A value chain analysis. Centre for the Promotion of Imports from developing countries. The Hague, p. 88.

29. World Bank (2013) FISH TO 2030. Prospects for Fisheries and Aquaculture. World Bank Report Number 83177-GLB, p. 102. 
This work is licensed under Creative Commons Attribution 4.0 Licens

DOI: 10.19080/OFOAJ.2017.05.555667
Your next submission with Juniper Publishers will reach you the below assets

- Quality Editorial service

- Swift Peer Review

- Reprints availability

- E-prints Service

- Manuscript Podcast for convenient understanding

- Global attainment for your research

- Manuscript accessibility in different formats

( Pdf, E-pub, Full Text, Audio)

- Unceasing customer service

Track the below URL for one-step submission https://juniperpublishers.com/online-submission.php 